\title{
Kesetaraan Gender dalam Iklan-Iklan Televisi Indonesia
}

\author{
Cherlita Christanti ${ }^{1}$, Obed Bima Wicandra ${ }^{2}$ \\ 1,2 Program Studi Desain Komunikasi Visual, Fakultas Seni dan Desain, Universitas Kristen Petra, \\ Jl. Siwalankerto 121-131, Surabaya \\ *Penulis korespondensi; Email: m42415076@john.petra.ac.id
}

\begin{abstract}
Abstrak
Iklan terkadang bias gender saat mempromosikan suatu produk. Perempuan sering menjadi objek yang seolah-olah hanyalah pelengkap tayangan iklan. Perempuan hanya diposisikan sebagai objek sensualitas maupun jenis kelamin kedua yang tak memiliki andil dalam pengambilan keputusan. Hal ini ditambah lagi dengan pandang umum dari masyarakat terkait perempuan. Konstruksi sosial menempatkan perempuan lebih lemah dan lebih tidak produktif daripada laki-laki dalam menyelesaikan pekerjaan, sehingga perempuan selalu diposisikan dalam wilayah domestik saja. Namun dalam perkembangannya, seiring dengan kritik sosial terhadap iklan, maka iklan kini mulai menempatkan kesadaran gender dalam konsep dan strategi periklanan. Mulai tumbuh iklan yang menempatkan perempuan setara dengan lakilaki, utamanya tidak saja menempatkan perempuan dalam tubuh yang sensual. Artikel ini mendeskripsikan dua iklan televisi, yaitu "Fair and Lovely" versi Nikah atau S2 dan iklan "Anlene Movemax" versi Karena Kita Lebih. Analisis menggunakan teori Simone de Beauvoire mengenai mitos dalam gender dengan menggunakan perangkat semiologi Roland Barthes. Simpulan dalam artikel ini adalah iklan televisi memiliki peran untuk mengubah stereotip mengenai perempuan, sehingga perlu adanya kepekaan dan perencanaan matang dalam membuat pesan komunikasi agar dapat mencapai target audiens dan berdampak pada perubahan sosial. Iklan-iklan dapat ditampilkan dalam berbagai sudut pandang: dari perempuannya sendiri, maupun dari sudut pandang orang ketiga agar pemirsa memahami bahwa perempuan memiliki posisi yang setara dengan laki-laki perihal peran sosialnya.
\end{abstract}

Kata kunci: Iklan, perempuan, kesetaraan, gender.

\begin{abstract}
Ads are sometimes gender-biased when promoting a product. Women are often the object of what seems to be a complement to ad impressions. Women are only positioned as objects of sensuality and the second sex who does not have a hand in decision making. This is coupled with the general view of the community regarding women. Social construction places women weaker and more unproductive than men in completing work, so women are always positioned in the domestic sphere only. But in its development, along with social criticism of advertising, advertising is now starting to place gender awareness in advertising concepts and strategies. Ads began to grow that put women on par with men, not only placing women in a sensual body. This article describes two television commercials, namely the "Fair and Lovely" version of Nikah or S2 and the Because We are More version of the "Anlene Movemax" commercial. The analysis uses Simone de Beauvoire's theory of myths in gender using Roland Barthes' semiological tools. The conclusion in this article is that television advertising has a role in changing stereotypes about women, so there needs to be sensitivity and careful planning in making communication messages in order to reach the target audience and have an impact on social change. Advertisements can be displayed from various perspectives: from the woman herself, or from a third-person point of view so that viewers understand that women have an equal position with men regarding their social roles.
\end{abstract}

Keywords: Advertising, women, equality, gender.

\section{Pendahuluan}

Patriarki merupakan keadaan masyarakat yang menempatkan kedudukan dan posisi laki-laki lebih tinggi dari pada perempuan dalam segala aspek kehidupan sosial, budaya dan ekonomi (Pinem, 2009). Pada kehidupan berumah tangga di Indonesia, misalnya, laki-laki dan perempuan dianggap telah memiliki peran tersendiri. Seorang laki-laki diposisikan sebagai puncak otoritas keluarga yang bertanggung jawab menafkahi keluarga dan mengambil keputusan bagi keluarga. Sedangkan, perempuan ditempatkan dalam wilayah domestik dalam keluarga, seperti mengerjakan pekerjaan rumah tangga, mengurus anak, dan memasak.

Konstruksi sosial menempatkan perempuan lebih lemah dan lebih tidak produktif daripada laki-laki dalam menyelesaikan pekerjaan, sehingga baiknya ada dalam wilayah domestik saja. Selain itu, 
perempuan juga memiliki tugas untuk melayani suaminya dengan baik. Hal tersebut kemudian menjadi stereotip dalam masyarakat dan secara turun temurun dipolakan. Akibatnya, perempuan kerap kali dituntut untuk tak perlu bersekolah tinggi karena ia akan menikah dan mengurus anak. Ironisnya, kebanyakan perempuan cenderung menerima perlakuan tersebut.

Pandangan tersebut tidak bisa dilepaskan dari mitos yang ingin dikembangkan. Bagi laki-laki penggunaan mitos adalah ampuh untuk mengontrol perempuan. Mitos yang merupakan penjelasan yang tidak dapat dijelaskan, menyederhanakan yang rumit, dan merasionalkan yang irasional, digarisbawahi oleh Beauvoir dalam menjelaskan mitos laki-laki terhadap perempuan. Pertama, apa yang diinginkan laki-laki dari perempuan adalah yang tidak didapatkan oleh laki-laki, dan kedua, perempuan adalah bisu seperti alam (1987: 224279). Penjelasan tersebut menempatkan perempuan sebagai objek sekaligus kelas jenis kelamin kedua; yang dianggap tidak penting.

Media massa (sebagai agen sosial) sering menggambarkan sosok perempuan sebagai objek dalam iklan-iklan maupun publikasi, misalnya dalam iklan parfum AXE, di mana si pengguna (laki-laki) dapat menarik perhatian beberapa perempuan sekaligus berkat penggunaan parfum tersebut. Contoh lainnya, perempuan sering digunakan sebagai 'alat' oleh pengiklan untuk meningkatkan penjualan dengan cara memberi image 'seksi' pada perempuan. Tindakan menampilkan perempuan dengan sudut pandang demikian yang sudah terlalu sering pada akhirnya membentuk persepsi masyarakat terhadap perempuan. Mereka seakanakan tidak tampak sebagai manusia yang sama derajatnya dengan laki-laki, melainkan hanya objek saja. Kasus-kasus di atas mewakili bagaimana ketimpangan gender di Indonesia terjadi.

Ketidakadilan yang sudah lama berlangsung ini mulai ditentang dengan munculnya gerakan feminis di Indonesia. Feminisme merupakan berbagai gerakan politik, ideologi, dan gerakan sosial yang berbagi tujuan bersama: untuk mendefinisikan, menetapkan, dan mencapai kesetaraan politik, ekonomi, pribadi, dan sosial dari jenis kelamin. (Hawkesworth, 2006).

Pada masa sebelum kemerdekaan, konsep kesetaraan gender belum begitu dikenal oleh masyarakat. Adapun bentuk perjuangan nyata para tokohnya, sebut saja R. A. Kartini yang berjuang untuk kesetaraan hak belajar dan Cut Nyak Dhien yang melampaui batasan perempuan sebagai pekerja domestik dan pergi berperang melawan
Belanda. Awal kebangkitan gerakan feminisme di Indonesia diawali pada tahun 1912, dimana organisasi Poetri Mardika berdiri untuk memperjuangkan hak pendidikan perempuan serta meneruskan semangat Kartini.

Organisasi perempuan kemudian mulai dapat berkembang secara progresif, sehingga memunculkan gagasan-gagasan untuk kesetaraan gender di organisasi lainnya. Hasilnya, pada tahun 1920, organisasi Sarekat Rakyat menyuarakan kesetaraan upah bagi pekerja perempuan. Dengan dukungan yang baik, dalam kurun waktu satu dekade lebih, organisasi perempuan berkembang dan pada saat itu terdapat lebih dari 30 organisasi perempuan.

Pasca kemerdekaan saat Orde Lama, tepatnya pada 1950; Gerwani (Gerakan Wanita Indonesia) berdiri sebagai organisasi perempuan yang menyuarakan hak-hak perempuan dan anak-anak, serta bergerak di bidang sosial-politik. Anggota Gerwani tak sekedar bekerja sebagai ibu dan istri di rumah, namun turut serta berpolitik dengan mencalonkan kader-kader pada Pemilu 1955. Sayangnya, ketika kebangkitan perempuan untuk kesetaraan baru terangkat, organisasi ini disingkirkan pada masa Orde Baru sehingga perempuan harus teropresi kembali (Khuluk, 2017: 13).

Runtuhnya Orde Baru membangkitkan semangat feminis di era milenial. Hingga saat ini, gerakan feminis tumbuh subur, terbukti dengan munculnya sejumlah komunitas-komunitas pendukung kesetaraan gender serta adanya acara Women's March di berbagai kota besar di Indonesia sejak 2017.

Kebangkitan gerakan feminis ini menimbulkan adanya perubahan sosial dalam masyarakat. Nilainilai tradisional mengenai perempuan telah bergeser, menempatkan perempuan sejajar dengan laki-laki, sehingga kedua gender sama-sama layak mendapatkan hak belajar, hak memimpin, hak bersuara, hak berpolitik, dan hak memilih yang sama. Namun demikian di balik semua itu, masyarakat yang masih teropresi pada budaya patriarki belum sepenuhnya menerima kehadiran gerakan feminisme ini.

Di zaman teknologi ini, media sangat berpengaruh sebagai pembawa pesan terutama pesan-pesan komersial dalam bentuk iklan. Media massa memiliki peran dan tanggung jawab sebagai perantara penyebaran pengetahuan kepada masyarakat, bukan hanya mengapitalisasinya untuk kepentingan pribadi dan golongan dengan cara mengeksploitasi perempuan (Prasanti dan Janitra, 2016: 49). 
Kini kecenderungan para produsen produk gencar menyuarakan pesan kesetaraan gender melalui iklan-iklan televisi. Penggambaran figur perempuan dalam iklan sebagai perempuan berpendidikan dan kuat mempengaruhi persepsi masyarakat agar menggeser persepsi masyarakat lama dan menciptakan perubahan sosial yang mengarah ke kesetaraan gender. Artikel ini hendak mendeskripsikan bagaimana iklan-iklan mulai membuka kesadaran baru mengenai kesetaraan gender dalam setiap strategi periklanan mereka.

\section{Pembahasan}

Televisi merupakan media komunikasi massa yang memiliki penetrasi tertinggi di Indonesia, yakni sebesar 96 persen (Nielsen Indonesia, 2017). Sebagai media yang mudah diakses dan cukup murah untuk dinikmati oleh berbagai kalangan, televisi tak hanya menyajikan program televisi, namun juga menayangkan iklan. Pada bulan MeiOktober 2017 sendiri, terdapat 2,7 juta spot iklan, 22 persennya ada di dalam program. Pemirsa TV sendiri didominasi oleh kelompok umur 20-29 dengan prosentase $20,1 \%$, disusul dengan umur 30 39 dengan prosentase 19,7\%. Dengan banyaknya penonton dan spot yang tersedia, para pengiklan memanfaatkan kesempatan ini dengan menyuarakan pesan mengenai kesadaran gender.

Iklan televisi yang diamati dalam artikel ini dalam menyuarakan kesadaran gender adalah iklan "Fair and Lovely". Latar iklan bertempat pada suasana makan siang. Suasana makan siang berkonotasi bahwa ada hal yang hendak dibahas, mengacu pada kebiasaan orang Indonesia yang suka berkumpul untuk mengobrol saat makan. Tokohtokoh ayah (Gambar 1), ibu (Gambar 2), dan anak (Gambar 3) digambarkan dengan pakaian yang bagus. Hal ini menunjukkan bahwa mereka kelas menengah ke atas.

Iklan tersebut diawali dengan seorang ayah yang mengatakan: "Kita punya jodoh yang cocok untukmu, terpelajar, karirnya bagus.” Kemudian, anak perempuannya menjawab: "Tapi Pa, bagaimana dengan S-2-ku?" dan ibunya menyetujui ayahnya seraya menambahkan dalam dialognya: "Nikah itu memang penting, Nak."

Dari dialog tersebut tergambarkan bahwa budaya patriarki masih kental, ditandai dengan adanya budaya menjodohkan anak perempuan dengan lelaki yang berkualitas serta cenderung mengabaikan kualitas keperempuannya. Kecenderungan pola pikir seperti itu tak hanya terjadi pada kaum menengah ke bawah, namun juga dengan kaum menengah ke atas, seperti pada iklan.

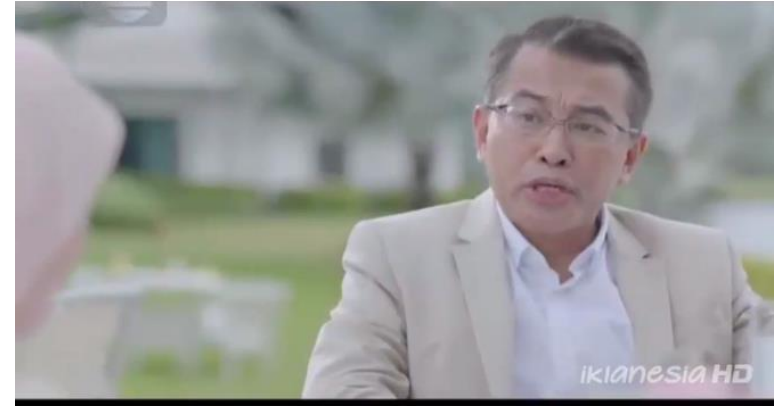

Gambar 1. Sosok ayah

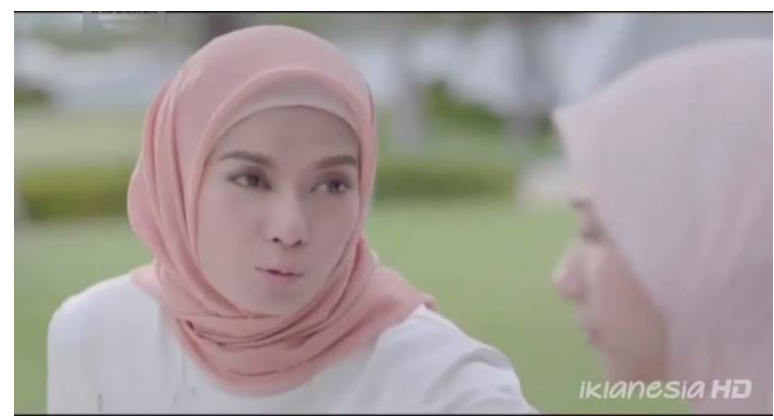

Gambar 2. Sosok ibu

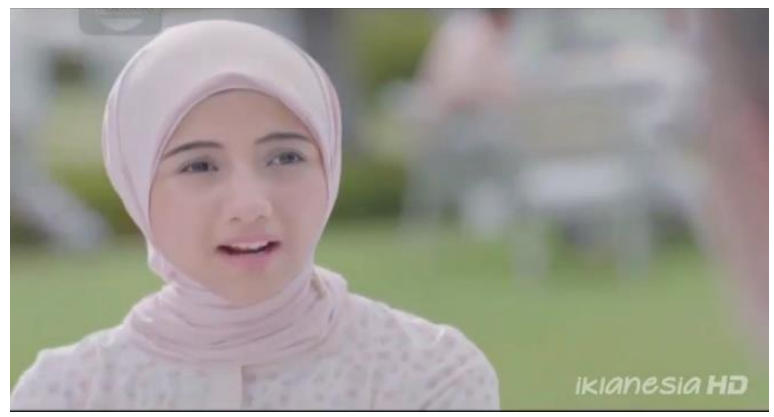

Gambar 3. Sosok anak

Penekanan 'nikah itu penting' seakan menjadi doxa dalam iklan tersebut karena si anak tak bisa mempertanyakan dan tidak langsung bisa menanggapi. Pada lingkungan dengan budaya patriarki yang kuat, pandangan itu terlihat biasa saja. Hal tersebut menggambarkan mengenai perempuan yang distrukturasi oleh masyarakat untuk hanya memikirkan mengenai pernikahan. Menikah dan membina keluarga kemudian dipandang menjadi suatu hal yang 'wajib' bagi perempuan.

Seringkali, perempuan yang tak kunjung menikah sering dicap negatif oleh masyarakat, serta menjadi aib keluarga. Hal tersebut mengakibatkan orang tua yang memiliki anak perempuan sangat mementingkan pernikahan dan kelangsungan keturunan untuk menjaga nama baik keluarganya. Dalam hal ini perempuan diobjektifikasi sebagai 'alat' untuk gengsi keluarga. Tentunya, calon suami yang berkualitas baik juga akan menaikkan nama baik keluarga karena dipandang sebagai calon kepala keluarga, sedangkan kualitas calon istri cenderung diabaikan. 
Adegan iklan kemudian berlanjut (Gambar 4 dan $5)$.

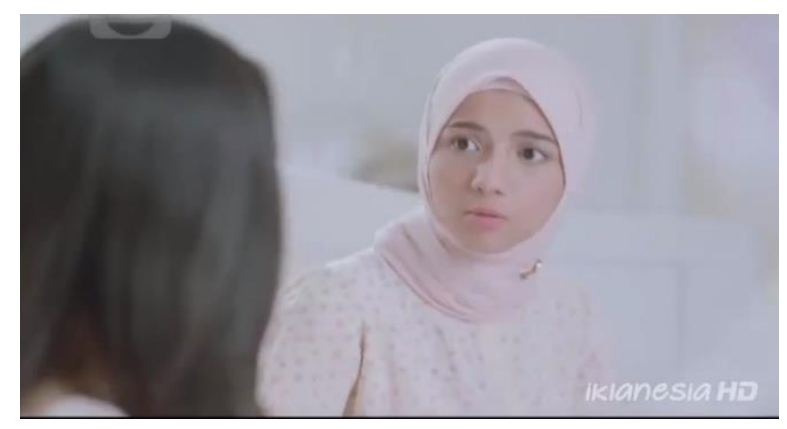

Gambar 4. Sosok anak yang bertanya pada temannya.

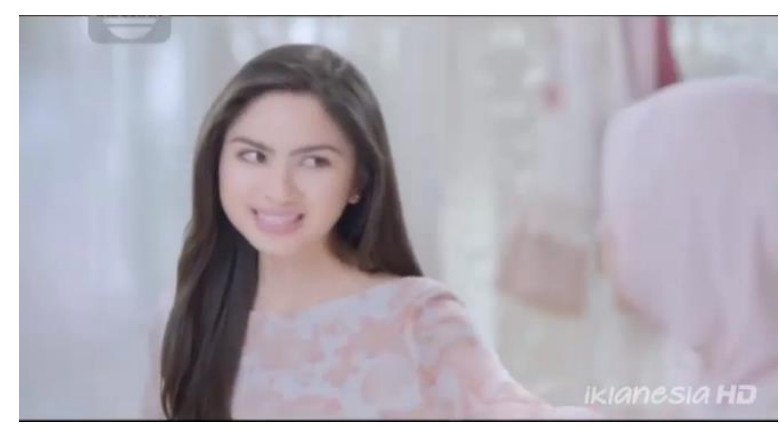

Gambar 5. Sosok teman

Ketika sedang bergumul dengan pikirannya sendiri, sang anak kemudian bertanya kepada temannya: "Nikah atau S-2?". Temannya menjawab: "Kamu pasti menemukan jawabannya.”. Adegan kemudian menampilkan produk "Fair and Lovely" dan efek penggunaannya (Gambar 6) yang seolaholah menampakkan petunjuk bahwa si anak telah mendapatkan jawabannya.

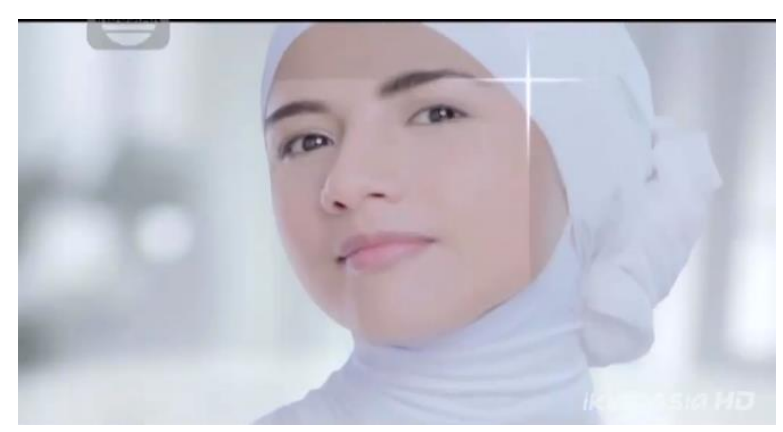

Gambar 6. Setelah si anak memakai produk, ada tanda yang menunjukkan si anak sudah menemukan jawabannya sendiri.

Pergumulan yang ditunjukkan dalam iklan ini merupakan representasi dari pergumulan perempuan di Indonesia sehari-hari yang sering dibombardir dengan pertanyaan-pertanyaan pribadi seperti tentang pernikahan, keturunan, dan sebagainya yang menyangkut 'nilai' perempuan tersebut di mata masyarakat, sehingga kebebasan perempuan semakin terkekang ketika harus menyesuaikan diri dengan 'nilai' tersebut.

Adegan (Gambar 7 dan 8) kemudian diteruskan dengan pernyataan sang anak: "Oke aku akan menikah, tapi setelah lulus S-2.” Ayah dan ibunya bingung. Ekspresi ini menandakan bahwa keputusan anaknya tidak mereka duga. Anaknya melanjutkan: "Seperti dia, aku juga harus terpelajar, punya karir bagus, baru kita berdua akan jadi jodoh yang pas, jadi sama, kan?”. Adegan kemudian ditutup dengan tampilan "Fair and Lovely".

Iklan tersebut ingin mengungkapkan kepada pemirsanya mengenai pilihan: pilihan untuk mengikuti patriarki atau menjadi setara (termasuk tentu saja pilihan untuk menggunakan produk "Fair and Lovely").

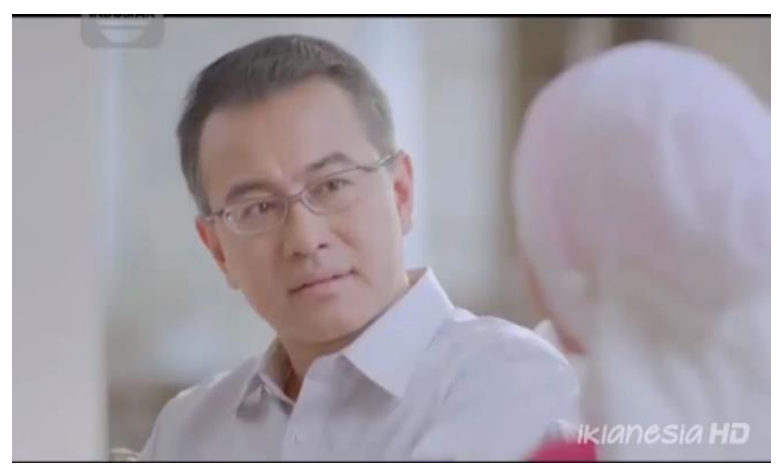

Gambar 7. Sang ayah saat mendengarkan pendapat anak

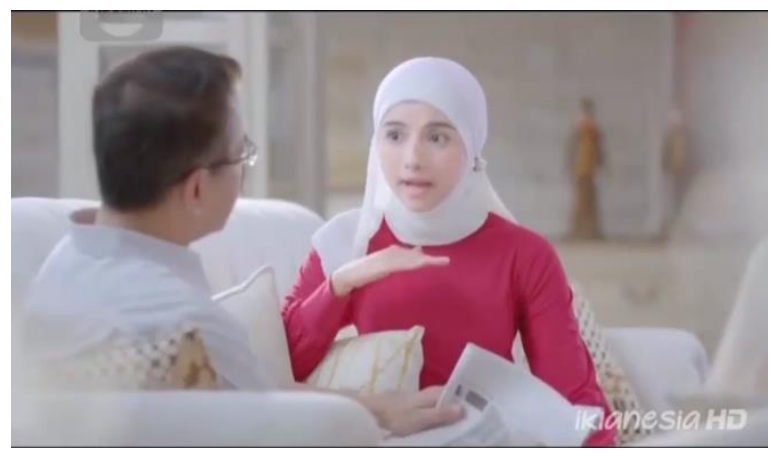

Gambar 8. Sang anak memberikan pernyataan dan pendapat.

Bila dianalisis dengan teori semiologi Roland Barthes, makna kalimat "jadi sama, kan?" memiliki konotasi bahwa sebelumnya ada ketimpangan, dalam hal ini gender. Figur perempuan dalam iklan ini yang mulanya tertekan dengan budaya patriarki memilih untuk menjadi setara dengan calon suami yang dipersiapkan orang tuanya. Ia memilih untuk menjadi terpelajar dan berkarir bagus dulu, baru menikah. 
Perubahan warna baju si anak dari hari pertama yang memakai warna putih agak pink ke hari selanjutnya yang memakai warna merah juga memberikan petunjuk. Warna merah sering diidentifikasikan sebagai makna keberanian. Pada konteks iklan ini, si anak berani mengungkapkan gagasan dan pendapat kepada orang tua. Tentu saja hal ini merupakan lompatan besar dalam kesadaran gender. Perempuan selama ini ditempatkan dalam posisi diam dan tidak banyak bicara. Pada iklan "Fair and Lovely", stereotipe ini berusaha dipatahkan.

Iklan tersebut biasanya ditayangkan pada jeda acara gosip infotainment dan sinema elektronik (sinetron), di mana penontonnya didominasi oleh perempuan dewasa muda dan perempuan dewasa. Memiliki status ekonomi menengah dan menengah ke bawah. Iklan "Fair and Lovely" memuat pesan tak langsung mengenai kesadaran gender dan isu kesetaraan yang mengajak penontonnya untuk memiliki keberanian agar perempuan lebih setara.

Iklan lain yang juga menarik untuk dikaji dalam konteks kesetaraan gender adalah iklan Anlene Movemax. Iklan ini menarik dalam mengajak perempuan menjadi kuat untuk melampaui 'batasbatas' dan stigma dari masyarakat. Anlene Movemax adalah produk susu bagi perempuan usia 19 hingga 50 tahun. Pada iklan ini juga ditampilkan satu figur laki-laki paruh baya sebagai pesepeda freestyle.

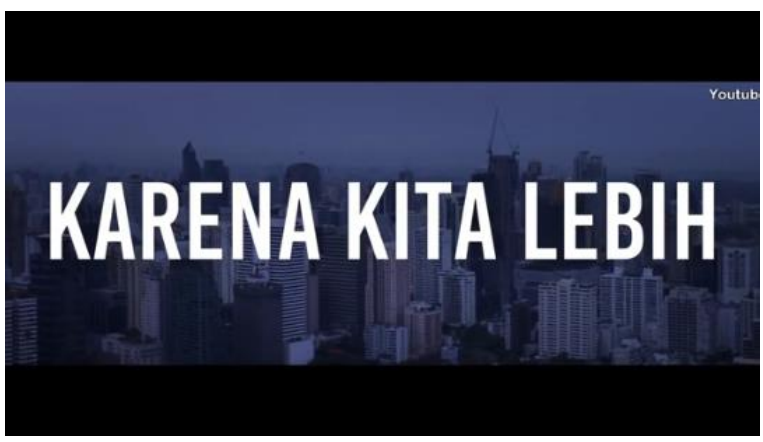

Gambar 9. Pembuka iklan

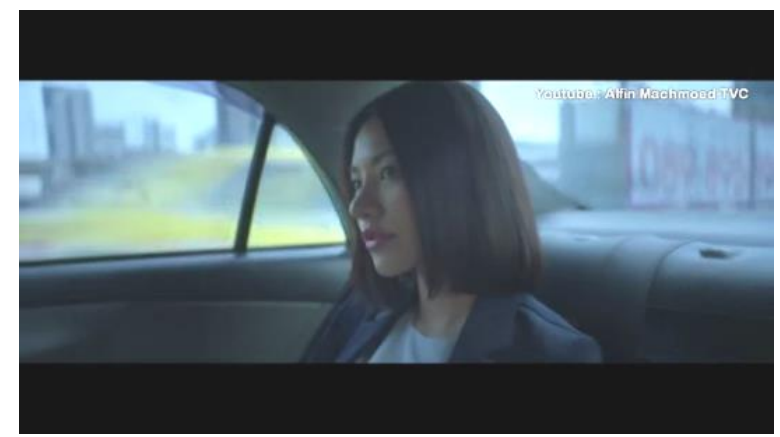

Gambar 10. Figur perempuan pembuka dalam iklan Anlene
Iklan diawali dengan pemandangan sebuah kota, kehidupan modern perempuan zaman kini. Tergambar kata 'KARENA KITA LEBIH' (Gambar 9), sebagai statement dari iklan tersebut, mengajak penontonnya untuk memiliki semangat dalam diri untuk melampaui batasnya. Kemudian, iklan melakukan transisi menjadi lima cerita paralel, yaitu perempuan-perempuan dengan berbagai macam pekerjaan dan kegiatan: koki, aktivitas olahraga Muay Thai, pekerja kantoran sekaligus disc jockey (DJ), dan mahasiswa yang sekaligus istri. Hal tersebut ingin memecah stereotip soal perempuan yang sering ditempatkan hanya di area domestik. Visual dari iklan ini membuktikan bahwa perempuan bisa lebih dari persepsi masyarakat.

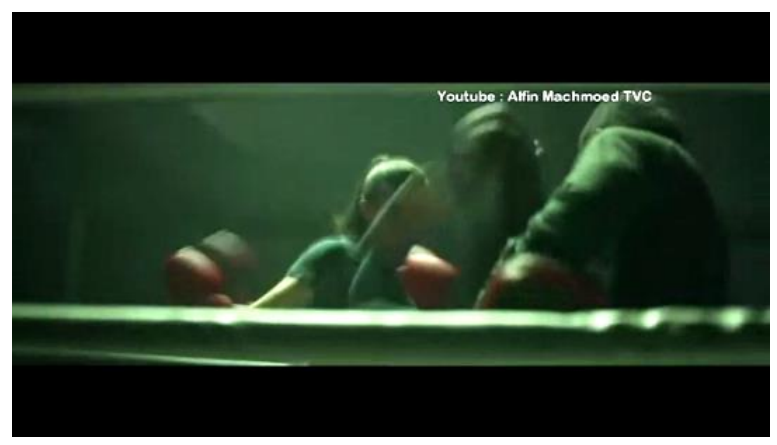

Gambar 11. Aktivitas perempuan bertinju jenis Muay Thai

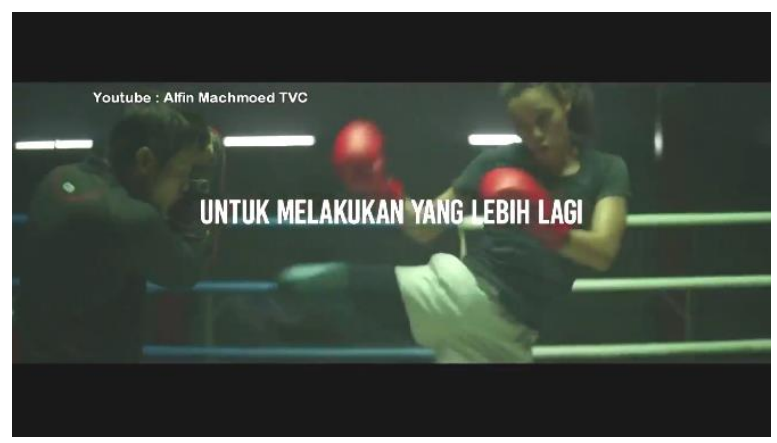

Gambar 12. Teks di sela-sela iklan

Cerita pertama dalam iklan ini adalah perempuan yang melakukan olahraga tinju a la Muay Thai (Gambar 11 dan 12). Olahraga ini biasa distereotipisasi dengan maskulinitas, laki-laki, dan kekerasan. Dalam istilah lain 'sangat tidak keperempuanan' bagi masyarakat pada umumnya. Namun perempuan aktif ini berhasil membuktikan diri bahwa dia kuat dan bisa melakukannya, sekaligus sebagai ekspresi dirinya. Apalagi, lawan yang dihadapinya digambarkan sebagai laki-laki, menggambarkan bahwa ia bisa mengimbanginya.

Cerita kedua melibatkan seorang laki-laki paruh baya (Gambar 13-15). Figur laki-laki paruh baya menyelip dalam iklan yang didominasi oleh figur perempuan. Laki-laki ini melakukan olahraga 
sepeda freestyle. Bahwa kemudian iklan ini ingin menunjukkan bahwa produk susu yang diiklankan ini penting bagi tulang dan persendian di usia senja, namun menarik menempatkan laki-laki di tengah dominasi figur perempuan yang aktif tidak hanya pada laki-laki.

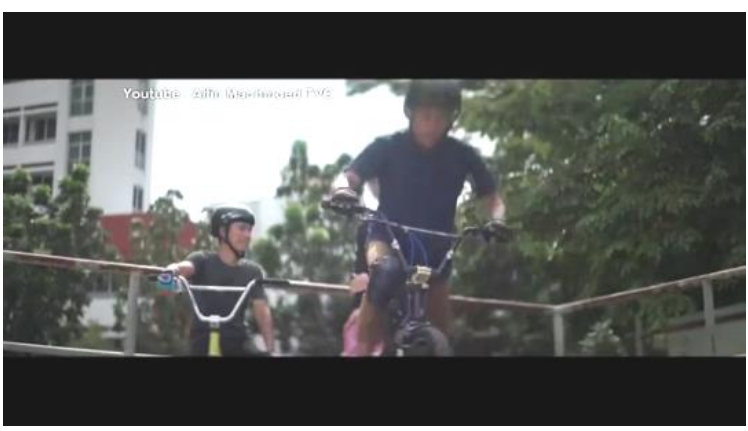

Gambar 13. Figur laki-laki pesepeda freestyle

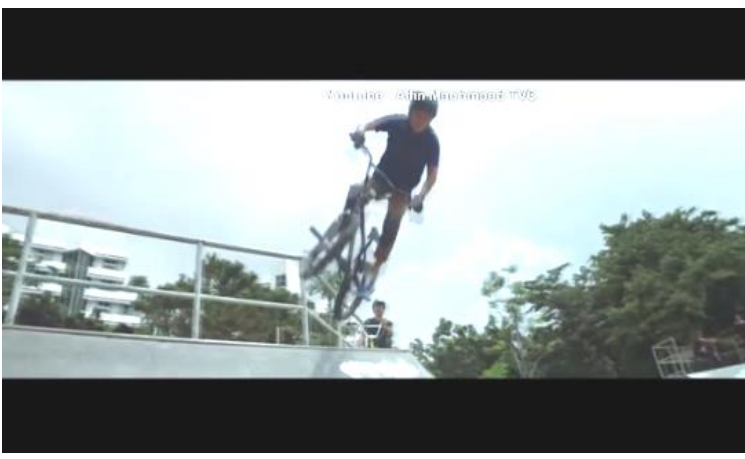

Gambar 14. Aksi pesepeda freestyle

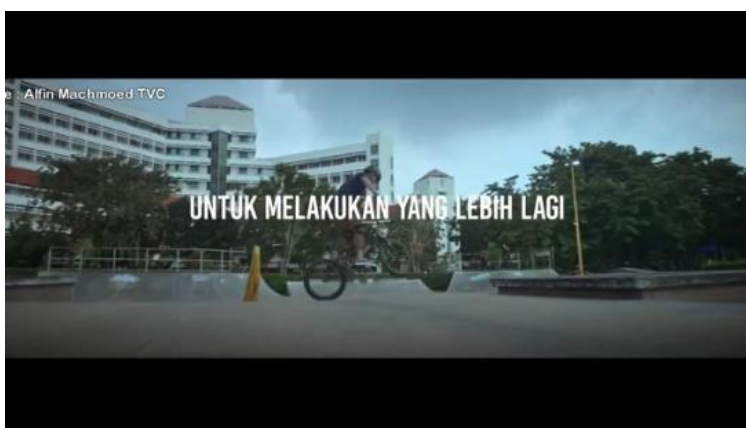

Gambar 15. Teks di sela-sela iklan

Cerita ketiga bercerita mengenai seorang perempuan yang berkarir sebagai pekerja kantoran pada siang hari, namun pada malam hari ia bekerja sebagai disc jockey (Gambar 16-17). Pada visualnya, terdapat laptop dan dialog menandakan ada meeting. Berarti ada suatu hal krusial yang harus dibahas dan orang yang terlibat di dalamnya merupakan orang-orang penting. Si perempuan duduk di tengah, menandakan ia adalah seorang pemimpin rapat, membuktikan bahwa perempuan juga bisa jadi pemimpin dalam pekerjaannya. Sedangkan pada malam hari, ia aktif menjadi disc jockey. Hal tersebut ingin menunjukkan bahwa perempuan bisa keluar dari area domestik dan berkarir, bahkan menjalani dua karir sekaligus.

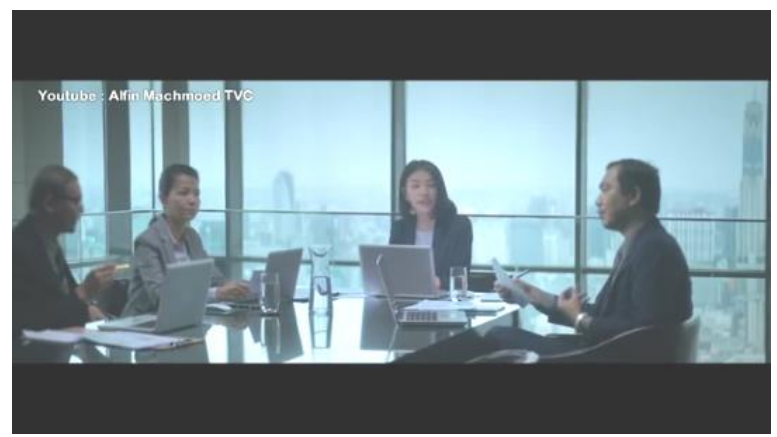

Gambar 16. Figur perempuan kantoran sekaligus DJ

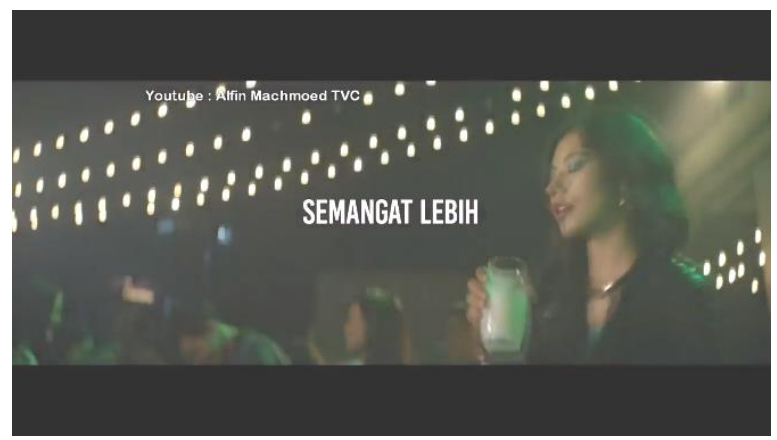

Gambar 17. Figur perempuan kantoran sekaligus DJ saat malam hari

Cerita keempat adalah cerita mengenai seorang istri yang baru saja lulus S-2, divisualkan dengan upacara kelulusan dan dihadiri suaminya (Gambar 19-20). Di bangku kelulusan, lebih banyak lelaki daripada perempuannya, menandakan tidak banyak perempuan yang bisa berpendidikan sampai tinggi. Hal ini ingin menekankan bahwa perempuan dapat berpendidikan tinggi dan setara dengan laki-laki, lagi-lagi menerobos stigma masyarakat. Masyarakat melakukan konstruksi pada diri perempuan sebagai sosok yang tak perlu sekolah tinggi-tinggi toh nantinya juga akan menikah.Iklan ini seolah-olah ingin mematahkan stereotip tersebut, dengan menggunakan copy sebagai penutupnya: "Lebih dari seorang istri".

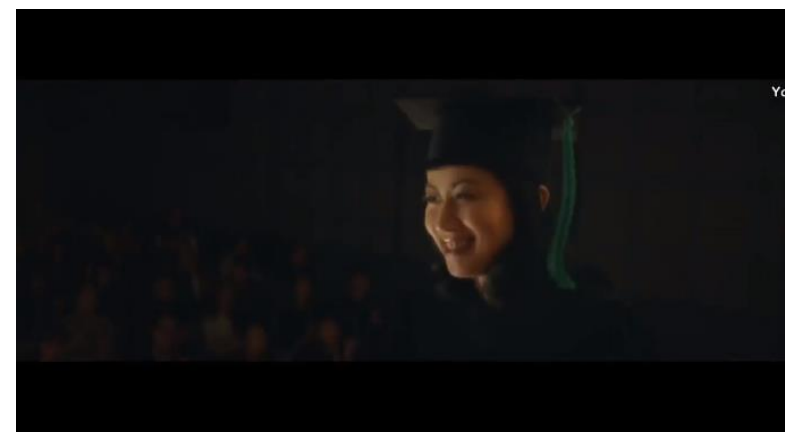

Gambar 18. Adegan perempuan lulus S-2 


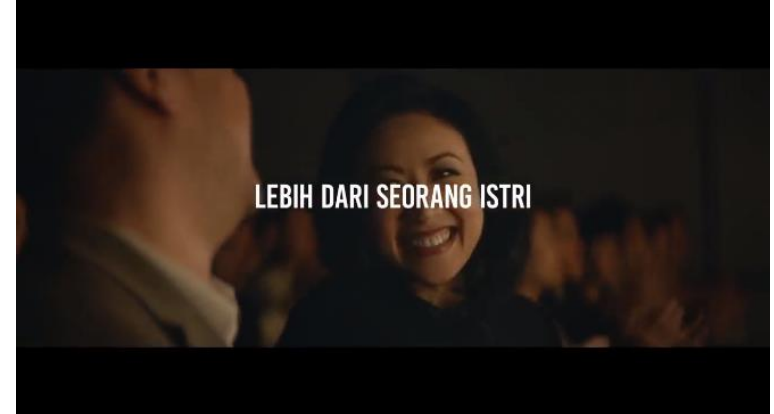

Gambar 19. Teks pada adegan istri yang sekolah lagi

Cerita terakhir adalah mengenai perempuan yang bekerja sebagai koki (Gambar 21-22). Berbeda dengan figur perempuan sebelumnya, dalam cerita ini digambarkan perempuan yang memakai jilbab. Bisa dibaca sebagai perempuan relijius yang setara. Hal ini dikarenakan stereotip perempuan berjilbab adalah mereka yang hanya di rumah saja, melakukan aktivitas di rumah, dan melayani suami. Di sisi lain, iklan ini juga ingin membenturkan stigma masyarakat yang menyepelekan aktivitas memasak hanya diposisikan pada urusan domestik. Iklan ini menggambarkan bagaimana memasak menjadi aktivitas di luar rumah juga. Hal tersebut ditunjukkan dalam iklan yang menampilkan keadaan dapur yang hectic.

Voice over iklan berbunyi: "Kita yang berjuang, dalam mendapatkan yang lebih" menandakan bahwa selama ini, untuk melampaui batasannya (atau batasan yang secara tak langsung sudah ada di masyarakat), perempuan masih harus berjuang. "Karena kita lebih: lebih dari usia kita, lebih dari pekerjaan kita, lebih dari seorang istri, lebih dari yang terlihat.", pesan ini mengajak perempuan untuk melampaui batasan tersebut. Seringkali faktor usia, pekerjaan di rumah, peran sebagai istri, dan penampilan perempuan dihakimi oleh orang lain dan menimbulkan minder bagi seorang perempuan untuk melangkah ke luar zona nyamannya, sehingga inilah ajakan bagi mereka.

Dan kita butuh susu yang memberikan lebih: kekuatan lebih, semangat lebih, untuk melakukan yang lebih lagi. Anlene movemax, lebih dari sekedar susu.' Kalimat ini mengimplikasi bahwa yang dilakukan oleh para perempuan ini sangat banyak, aktif, dan hebat, sehingga membutuhkan kekuatan yang lebih.

Secara keseluruhan iklan-iklan tersebut tidak secara terang-benderang berbicara soal kesetaraan, namun iklan ini ingin mengomunikasikan soal pembuktian bahwa perempuan itu hebat untuk menembus doxa yang ada di masyarakat agar bisa setara dengan laki-laki. Meskipun tak ada dialog, namun latar dan visualisasinya menunjukkan kemampuan perempuan sesungguhnya. Sama seperti iklan "Fair and Lovely", iklan ini ditayangkan pada jeda acara sinetron dengan mayoritas penonton perempuan dewasa muda hingga dewasa.

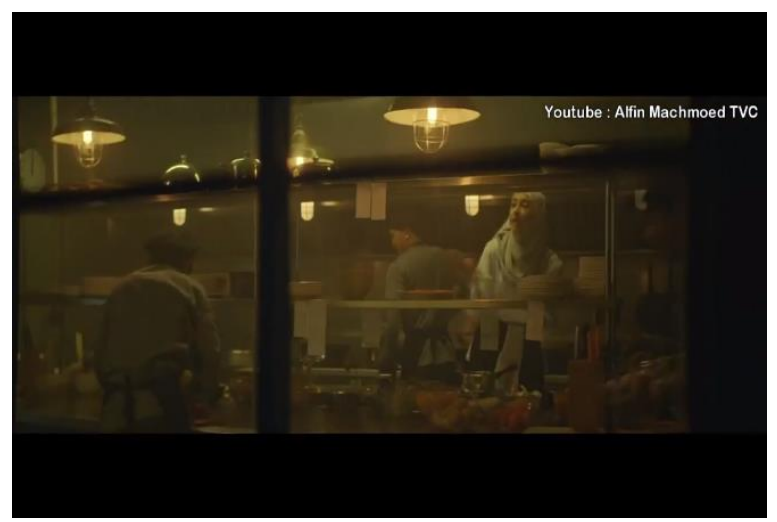

Gambar 20. Figur perempuan berprofesi koki yang sibuk di dapur restorannya

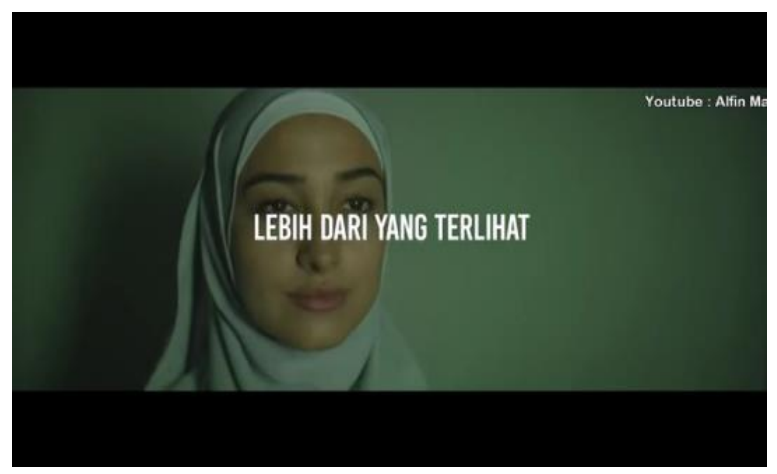

Gambar 21. Teks pada adegan perempuan koki restoran

Selain dua iklan tersebut, masih banyak iklan di Indonesia yang berbicara soal kesetaraan gender yang muncul belakangan ini (2017-2018), diantaranya Lux Velvet Jasmine, Dove Total Hair Fall Treatment, Sunlight Kue Nastar Tuti, Sunsilk Shampoo \& Conditioner, dan masih banyak lagi.

Meskipun pesan itu juga memiliki elemen komodifikasi (untuk menjual komoditas tertentu), kemunculan berbagai iklan dengan pesan kesetaraan gender ini merupakan stimulus bagi masyarakat untuk mulai membangun persepsi positif mengenai perempuan dan kesetaraan mereka dengan laki-laki. Apabila iklan-iklan terus menyuarakan kesetaraan, dan didukung oleh kegiatan atau aktivasi serupa, maka lama-kelamaan pola pikir masyarakat dapat bergeser ke arah yang lebih positif mengenai perempuan, sehingga membentuk habitus baru. Lingkungan yang membiasakan diri dengan kesetaraan gender akan berpengaruh kepada individu-individu di dalamnya, sehingga dapat mengubah masyarakat yang patriarki. 


\section{Simpulan}

Budaya patriarki masih lekat akarnya di Indonesia, namun sebenarnya budaya tersebut dapat digeser oleh perubahan sosial. Perubahan sosial tersebut tidak semata-mata muncul secara langsung, melainkan melalui media-media perantara. Media perantara yang mudah, murah, dan populer untuk pemicu perubahan sosial tersebut yakni televisi. Melalui tayangan dan iklan-iklan yang ditayangkan oleh televisi, para pengiklan dapat menyampaikan maksud dan tujuannya. Dalam hal ini, pesan yang dimaksudkan adalah pesan mengenai kesetaraan gender untuk menguatkan posisi perempuan di negara yang masih kental akan budaya patriarki ini.

Iklan-iklan dapat ditampilkan dalam berbagai sudut pandang: dari perempuannya sendiri, maupun dari sudut pandang orang ketiga agar pemirsanya paham perjuangan perempuan dalam menyetarakan diri. Kebanyakan iklan yang memiliki pesan mengenai kesetaraan gender ini ditayangkan pada acara-acara yang ditonton oleh perempuan dewasa muda dan dewasa. Hal tersebut menandakan bahwa perubahan sosial ini dikehendaki untuk muncul dari perempuannya sendiri dulu, lalu mempengaruhi lingkungannya.

Apabila hal tersebut dapat terjadi secara konsisten dan berkelanjutan, perubahan sosial ini dapat membentuk sebuah habitus baru yaitu lingkungan yang sadar akan kesetaraan gender dan memperlakukan pria dan perempuan secara setara.
Secara keseluruhan, iklan televisi memiliki peran untuk mengubah habitus tersebut, sehingga perlu adanya perencanaan matang dalam membuat pesan komunikasi agar dapat mencapai target audiencenya dan berdampak pada perubahan sosial.

\section{Daftar Pustaka}

AGB Nielsen. (2010). Data Highlights: Kendali di Tangan Para Lansia. AGB Nielsen Newsletter Edisi 3, Maret 2010. Diakses dari: http://www. agbnielsen.net/Uploads/Indonesia/AGBNielse nNewsletterMarch2010-Ind.pdf

De Beauvoir, Simone. (1987). The Second Sex. Trans: H.M Parshley. Great Britain: Penguin Books

Bernie, Moammad. (2017). Riset Nielsen: Iklan yan "Menyusup" di Program TV Makin Banyak. Diakses dari: https://tirto.id/riset-nielseniklan- yang-menyusup-di-program-tv-makinbanyak-cAvd

Hawkeswrth, Mary E. (2006). Globalization and Feminist Activism. Rowman \& Littlefield.

Khuluk, Muhammad Khusnul. (2017). Gerwani dalam Arus Kekuasaan: Studi Historis Politik Gerwani dalam Lingkaran Gestok, PKI, dan Politik Global. Skripsi. Surabaya: Program Studi Filsafat Politik Islam, Fakultas Ushuluddin dan Filsafat, UIN Sunan Ampel.

Pinem. Saroha. (2009). Kesehatan Reproduksi dan Kontrasepsi. Jakarta: Trans Info Media.

Prasanti, Ditha, Janitra, Preciosa Alnashava. (2016). Representasi Perempuan dalam Iklan "Fair and Lovely" Versi Nikah atau S2. Jurnal Ilmu Politik dan Komunikasi. 6(1): 47-66. 